\title{
BREVE MEDITACIÓN SOBRE LA MÚSICA
}

Juan Carlos Mansur*

\section{Hablar de música es ya un intento} por decir algo sobre lo indecible. Indagar la esencia de la música no logra más que ahondar el misterio de este arte, que no parece tener que ver con el mundo y que mora enclavado en el corazón del hombre. Aun cuando la naturaleza emite sonidos, nada de ella es propiamente música, el canto y la melodía rebasan por mucho la realidad sonora del universo, y más que imitar la naturaleza, parece que el músico crea a partir de su propio espíritu. "Ciertas clases de música parecen ser un directo mensaje del alma divina o del alma del hombre”, afirmaba Stokowsky, para hacernos ver que la música es el arte más alejado de la representación, y en mucho la más cercana al corazón. O como diría Hanslik:

El compositor no puede transformar absolutamente nada, tiene que crear todo de nuevo. Lo que el pintor o el escritor halla en la contemplación de lo naturalmente bello, lo tiene el compositor que elaborar concentrándose en sí mismo. Tiene que esperar la hora propicia en que comienza a sonar y resonar algo en sus adentros; entonces se ensimismará y creará, extrayendo de su propia sustancia, lo que no tiene en la naturaleza y que, por consiguiente y en contraste con las demás artes, cabalmente no es de este mundo. ${ }^{1}$

\footnotetext{
* Departamento Académico de Estudios Generales, ITAM.

${ }^{1}$ Eduard Hanslik, De lo bello en la música, Ricordi, Buenos Aires, 1947, p. 111.
} 
De nuevo: aunque la naturaleza emita sonidos, nada de ella es propiamente música; sin embargo, subsiste la paradoja, pues la música está íntimamente ligada con los principios del universo: el sonido, el silencio y el ritmo, así como la armonía y proporción matemática de la naturaleza, constituyen la raíz de toda música, tal como lo develan la antigua sabiduría de la raga y el nad de la India, y la enseñanza de la armonía y proporción egipcia y griega de la antigüedad, según la cual, el universo es una sinfonía -la música de las esferas y de la proporción matemática-, de cuyos principios brota toda verdadera música. Por eso la música nos transporta a realidades supremas, pues participa del principio y origen del cosmos y nos adentra en ellos, con lo cual se aprecia que ella es lo más próximo al universo y lo más alejado de él: el punto de encuentro entre lo espiritual y lo material.

Además de participar de la esencia cósmica, la música como todo arte, tiene un poder aún más grande: el poder de crear una nueva realidad; mediante la inspiración, el artista trae del mundo suprasensible las ideas más abstractas e infinitas, motor de todo hombre y toda cultura: la libertad, Dios, el alma, la justicia, la muerte, el dolor, el odio, el amor, y nos las entrega en forma de arte y cultura. La música se vale de los artistas para recrearse de infinitas formas, para crearse una y otra vez y hacer presente la fuerza de la vida en esta tierra. De ahí la importancia del artista: él completa la creación, inyectando de espíritu cuanto le rodea. Necesitamos de aquellos artistas que tengan el poder de traer el espíritu a este mundo sensible; algo se pierde en el mundo cuando muere un artista, pues el aporte personalísimo que hace al mundo se da sólo una vez y nunca más se repetirá de esa manera. Ha sido el papel que han tenido los artistas en toda época, crear un mundo, darle sentido y vida a la inerte existencia física. El Partenón devuelve a Grecia lo que de ella ha tomado, y la enmarca y le da sentido; Bach, Beethoven y Heine hicieron hablar a Alemania; los pueblos del Líbano y las costas del mundo árabe hablan gracias a la voz amorosa de Fairuz, al laúd profundo de Wadhi E'Saffi, o la voz de Um Kalthum; los patios andaluces de Granada visten y dan realce a la esencia de España que se adorna de la guitarra flamenca y de la 
obra de Albéniz, Granados y Rodrigo; México le debe sus cielos a Velasco y su espíritu a la música huasteca, a Ponce, a Ricardo Castro y Moncayo entre muchos otros. Lo que el artista toma del mundo, se lo devuelve con creces al realzar la esencia de la vida en cada obra. Más que descubrir la esencia del mundo, la música lo funda y lo crea. Ella hace sensible el mundo espiritual de los hombres y espiritualiza el mundo que nos rodea.

Este poder espiritual de la música se traduce en el poder de congregarnos y de conformar mundos; asociamos la música a épocas de la vida, a personas, a recuerdos; basta escuchar una conocida tonada para sentir acariciada el alma, no sólo para entrar en los recuerdos sino para estar en contacto con nuestra intimidad, con nuestro corazón y con la vida misma, principios que difícilmente pueden ser tocados de otra manera; por eso, todo lo festivo y toda conmemoración necesitan de la música, pues ella trae nuevamente lo esencial: poder de acercar y hacer volver lo que permanecía alejado o lo que estaba perdido, por ello se canta a la felicidad que atisba un sentido en la vida, lo mismo que a la tristeza, que implora por la unidad perdida; se canta a la vida como se canta a la muerte; se canta al amor o al odio, por esa necesidad de reunir, de convocar, de reconstituir lo que estaba separado: ése es el carácter simbólico de la música, principio de todo arte y de la que tanto han hablado innumerables pensadores a lo largo de toda la historia. Todos ellos han tratado de explicar magistralmente la fuerza unificadora de la belleza y del arte. Y así sucede con la música: frente a ella, cae el velo que divide, frente a la música más elevada, sucumbe la diabólica división y apatía, aniquiladora de toda unidad y vida. 
CITAM Derechos Reservados.

La reproducción total o parcial de este artículo se podrá hacer si el ITAM otorga la autorización previamente por escrito. 